\title{
Performance Study of Fresh and Hardened Properties of Palm kernel Shell -Rice Husk Ash Aggregate Concrete \\ ${ }^{1}$ Oyejobi, D. O., ${ }^{2}$ Raji, S. A. and ${ }^{3}$ Jimoh, A. A. \\ ${ }^{1,2,3}$ Department of Civil Engineering, University of Ilorin, Ilorin, Nigeria \\ Corresponding E-mail: oyejobi.do@unilorin.edu.ng
}

\begin{abstract}
This study produced light-weight aggregate concrete by replacing conventional dense aggregates of granite with palm kernel shells and sand with pozzolanic rice husk ash. Apart from cost reduction in the cubic metre of the concrete, the overall dead load was reduced; natural resources were preserved as wastes were re-used in a beneficiary manner. The levels of replacement were from 10 to $100 \%$ for both coarse and fine aggregates for thirteen different mix proportions. A unique mix-proportion based on the material properties of these non-conventional materials was designed with a water-cement ratio of 0.38 . This was followed with the study of behaviour of this mixture for its fresh and hardened properties and the result was compared with the conventional aggregates. With the range of 10 to $100 \%$ replacement, compressive strength values fell between 14.31 and 26.14 MPa. The Splitting tensile strength was found to be between 14 and 16\% of the compressive strength and the oven-dried density decreased with the increase in the quantities of rice husk ash and palm kernel shells respectively with the range between 1414 to $2302 \mathrm{~kg} / \mathrm{m}^{3}$. This class of concrete could be adopted for both plain and reinforced concrete with light-weight aggregate.
\end{abstract}

Keywords: light-weight concrete, palm kernel shells, rice husk ash, compressive strength, splitting strength

\section{Introduction}

Light-weight concrete can be produced through the following three principles which are no-fine, aerated and lightweight aggregate concrete, Newman and Choo (2003) either for structural or for non-structural applications. Wbcsd (2018) reported concrete to be the second highest most consumed substance after water, with an estimated figure of 30 billion tonnes of concrete was consumed all over the world as at 2006. By definition, concrete comprises of cement, coarse aggregates (granite), fine aggregate (sand) and water. The chief raw material for cement is limestone while both coarse and fine aggregates raw materials are natural resources from different rocks. The demerits of these ancient materials are that cements are not reusable, exploitation and transportation costs of aggregates are high, cause climate change during mining, exposed environment to danger and pollution. An attempt for finding alternative to these raw materials is the use of agro-industrial by-products which is the fulcrum of this paper. In another paper by the same author, complete replacement of cement had been carried out while this current work focused on the varying effects of palm kernel shells and rice husk ash as coarse and fine aggregates in different volumes. The physical properties of these alternative materials were carried out and subsequently used for the design of mix proportions.

Oil palm is considered as one of the most important economic oil crops in Nigeria with the production from more than two-third States of the whole Country. In the 50's and 60's, Nigeria was the world's leader in the production of palm kernel oil but this pride was lost to Malaysia and Indonesia as a result of discovery of crude petroleum PIND (2011). Palm kernel shells (PKS) are organic waste products that are left behind after the crude oil and nuts have been extracted from the oil plant. In Nigeria, PKS has been used as fuel in homes and industries. On the other hand, the drive for light-weight concrete and economic benefit of PKS over conventional aggregates has prompted the replacement of granite with palm kernel shells Oyejobi, Abdulkadir, Yusuf, and Badiru (2012). Various studies have used PKS as a partial replacement either in concrete, asphalt and pavement such as Ndoke (2006), and Yusuf and Jimoh (2011). In Kupaei, Alengaram, Jumaat, and Nikraz (2013), oil palm shells were used for fly ash based geopolymer concrete with the thirty-two trial mixes investigated by considering different variables such as mix proportions and activator concentration. The results showed that oil palm geopolymer concrete with a 
demoulded density of $1800 \mathrm{~kg} / \mathrm{m}^{3}$ containing fly ash binder of $480 \mathrm{~kg} / \mathrm{m}^{3}$, water-cement ratio of 0.4 was recommended for structural grade 30 concrete. In Olanipekun, Olusola, and Ata (2006), economic advantages of using palm kernel shell as light-weight aggregates, and the mechanical properties of palm kernel shell, and coconut shell concrete are compared with each other. The sizes of palm kernel shells in Nigeria as used by Okafor (1988) and Okpala (1990) were between 5 to $12.7 \mathrm{~mm}$, maximum thickness of $4 \mathrm{~mm}$ and range of specific gravity was between 1.17 and 1.37 respectively. Depending on the sand and palm kernel shells, the density of the light-weight concrete was reported by Alengaram, Jumaat, and Mahmud (2008) to be between 1700 to $2050 \mathrm{~kg} / \mathrm{m}^{3}$ with the 28-day compressive strength between 15 and $25 \mathrm{MPa}$. Also, a related study by TEO, Mannan, and Kurian (2006) reported the compressive strength of oil palm shell concrete to be $28.1 \mathrm{MPa}$ which is higher than the minimum required strength for structural light-weight concrete as recommended by ASTM C330 (2006). The workability and compressive strength of palm kernel shells concrete were studied by Daneshmand and Saadatian (2011) and at 28 days, strength of up to $52 \mathrm{MPa}$ was achieved. In a study of rice husk ash refractory, Onojah, Agbendeh, and Mbakaan (2013) performed an open air burning of the rice husk, cooled in an open environment for 24 hours and then a carbolite furnace was used to fire the ashes at a controlled temperature of $650^{\circ} \mathrm{C}$ producing a white amorphous rice husk ash. Similarly, Ettu, Ajoku, Nwachukwu, Awodiji, and Eziefula (2013), after airdrying the rice husk, fabricated a locally combustion chamber that was below $650^{\circ} \mathrm{C}$, as this for combustion of husk into ashes. Akogu and Obumneme (2013) and E. Abalaka (2013) produced RHA by using a charcoal fired incinerator at a recorded maximum temperature of $838^{\circ} \mathrm{C}$. In Agbenyeku and Aneke (2014) rice shells were sun-dried, burnt in open air and calcined in an electric furnace to a temperature of about $700^{\circ} \mathrm{C}$. Oyejobi, Abdulkadir, and Ajibola (2014) carried out partial replacement of cement with rice husk ash by burning rice husk at a controlled temperature of about $700^{\circ} \mathrm{C}$ for a period of four hours. The ash produced could be ground using mortar and pestle, Oyejobi et al. (2014) or hammer mill A. E. Abalaka (2013). However, in Ettu et al. (2013) while studying the compressive strength of concrete produced by partially replacing cement with RHA, did not mill the ash collected from RHA dump rather uses $600 \mu \mathrm{m}$ sieve and discarded the large particles retained on the sieve. Similarly Ogork and Uche (2014), Alabi, Olutaiwo, and Adeboje (2015), Okafor and Okonkwo (2009), Tsado, Yewa, Yaman, and Yewa (2014), Afolayan, Amartey, and Oriola (2015) used a $75 \mu \mathrm{m}$ sieve to get fine RHA while Oyekan and Kamiyo (2011) used $45 \mu \mathrm{m}$.

In the work of Opeyemi and Makinde (2012), the result show POFA with specific gravity of 2.02 while in Obilade (2014) it was between the range of $1.9-2.4$. The workability of fresh POFA-OPC concrete was shown to decrease with increase in the percentage replacement as measured by the slump test; this was attributed to the fact that POFA absorbed more water to form a paste of standard consistency than cement. POFA was used as a cement replacement up to $30 \%$ in producing high-strength concrete with higher compressive strength than the control (concrete made from Portland cement). A study of durability properties of palm oil fuel ash Self Compacting Concrete (SCC) by Ayininuola and Olaosebikan (2013) concluded that acid resistance and high strength SCC can be produced from the combination of palm oil fuel ash and Conplast SP432MS.

As at today, Nigeria's population is presently over 198 million as reported by National Population Commission (2018). This teeming population is faced with housing problems due to the low income and high prices of building materials. By exploring waste products from the industries for concrete production, the costs of construction will be reduced and houses will be affordable. Besides, there will be economic value for these wastes, and control of pollution associated with the wastes rather than open dumping on the land and into rivers. The aim of this study is to investigate the plastic and hardened properties of concrete made from alternative materials. This shall be carried out by determining the physical properties of palm kernel shell and rice husk ash as suitable for aggregates materials. Based on the physical properties from the aggregates, mix proportion shall be designed and mechanical behaviour of the concrete at different volume of these aggregates shall be investigated. However, this is in two-folds, which are preserving natural resources used for concrete construction (granite and sand) which upon exploitation exposed the whole place to environmental threats such as erosion, degradation, climate 
change as a result of greenhouse gases released during the production of these materials and controlling the environmental implications from the massive agro-industrial waste generated by industries through reuse. It is believed that incorporation of palm kernel shells and rice husk ash as aggregates will help in producing light-weight concrete which has several applications, cost-effective concrete, solve aggregate problem where there is depletion of the aggregates, conserve natural resources, reduce and re-use of agricultural by-products that are constituting a menace to the environment are made possible.

\section{Materials and Methods}

Elephant cement, a typical example of ordinary Portland cement that conforms with BS EN 197 (2011) was bought from the Post office market, Ilorin, Kwara State, Nigeria as this was used as a binder for the concrete production. Fine aggregates were sourced from a construction site at the University of Ilorin, Ilorin Kwara state, Nigeria and this conformed to BS 812 (1975). Besides, rice husk ash (RHA) was used for sand replacement. The rice husk was collected from rice mill factory located in Ilorin, Kwara state, Nigeria. This was pretreated and incinerated at $700^{\circ} \mathrm{C}$ temperature for four hours in order to obtain the ash. Particle size distribution of the ash was carried out using sieves $5.00 \mathrm{~mm}$ and below. The procedure for obtaining the ash and the chemical composition were accounted for in Oyejobi et al. (2014). Subsequently, palm kernel shells that are free of fibres were sourced from a local factory in Omu-Aran, Kwara state, Nigeria. The PKS were pre-treated by washing with detergent, rinsed, air-dried and stockpiled. PKS was then crushed and sieved to the desired size of aggregates passing through $16.5 \mathrm{~mm}$ sieve and retained on $5 \mathrm{~mm}$. The adopted aggregate size was chosen so as to avoid shells with a large surface area which has tendency for high water absorption and also to avoid fine materials based on the past study by Oyejobi et al. (2012). The physical properties of the PKS aggregates are as follows, the specific gravity of $1.54 \mathrm{~g} / \mathrm{cm}^{3}$, the bulk density of $630 \mathrm{~kg} / \mathrm{m}^{3}$, fineness modulus of 6.40 and water absorption of $16 \%$. Tap water from the laboratory was used in the concrete production which was in compliance with BS EN 1008 (2002).

Laboratory tests

Suitability of PKS and RHA as lightweight aggregates was determined by carrying out sieve analysis, specific gravity, water absorption, moisture content, and bulk density. Rice husk ash samples that passed through $4.75 \mathrm{~mm}$ and retained on 150 micron sieve were used as fine aggregate while PKS samples between $5.00 \mathrm{~mm}$ and $12.5 \mathrm{~mm}$ were used as coarse aggregate. Based on the physical properties of these materials, the mix design was carried out and the mix proportions in the Table 1 were used during the mixing process. The levels of replacement employed were 10, 30, 50, 70 and 100\% for both aggregates while the water cement ratio was kept constant at a value of 0.38 . The mixture was thoroughly mixed together in a rotating earth drum mixer while slump and compressive strength tests were performed on the concrete. With each mix ratio as presented in Table 1 , the batching of the mixes was done by weight with the concrete cubes of $150 \times 150 \times 150 \mathrm{~mm}$. The results of the compressive strengths, density, tensile and flexural strengths for 7 14, 21, 28 days were shown in Figures 2 to 4, respectively whereby each test age is an average of three identical samples.

Table 1: Mix proportions $\left(\mathrm{kg} / \mathrm{m}^{3}\right)$

\begin{tabular}{llllllllllllll}
\hline Mix ID & A1 & A2 & A3 & A4 & A5 & A6 & B2 & B3 & B4 & B5 & B6 & B7 & B8 \\
\hline Cement & 400 & 400 & 400 & 400 & 400 & 400 & 400 & 400 & 400 & 400 & 400 & 400 & 400 \\
$\begin{array}{l}\text { Fine } \\
\text { aggregates }\end{array}$ & 600 & 540 & 420 & 300 & 180 & 0 & 600 & 600 & 600 & 600 & 600 & 300 & 0 \\
$\begin{array}{l}\text { Coarse } \\
\text { Aggregates }\end{array}$ & 1200 & 1200 & 1200 & 1200 & 1200 & 1200 & 1080 & 840 & 600 & 360 & 0 & 600 & 0 \\
RHA & 0 & 60 & 180 & 300 & 420 & 600 & 0 & 0 & 0 & 0 & 0 & 300 & 600 \\
PKS & 0 & 0 & 0 & 0 & 0 & 0 & 120 & 360 & 600 & 840 & 1200 & 600 & 1200 \\
Water/cement & 0.38 & 0.38 & 0.38 & 0.38 & 0.38 & 0.38 & 0.38 & 0.38 & 0.38 & 0.38 & 0.38 & 0.4 & 0.38 \\
\hline
\end{tabular}




\section{Results and Discussions}

Sieve analysis and specific gravity

The results of the rice husk ash and palm kernel shells sieve analysis show that there was a good distribution of aggregates between the $2.36 \mathrm{~mm}$ and $0.075 \mathrm{~mm}$ for rice husk ash aggregates and a wide spread of palm kernel shells aggregates occurred between the $14 \mathrm{~mm}$ and $6 \mathrm{~mm}$ sieve sizes as shown in the Figure 1 respectively. The implication of this was that the homogeneous mix was ensured from these varying particles of aggregates. The specific gravities of palm kernel shells and rice husk ash in this study were 1.54 and 2.57 which are lower than the specific gravities of 2.45 and 2.8 for sand and granite respectively.
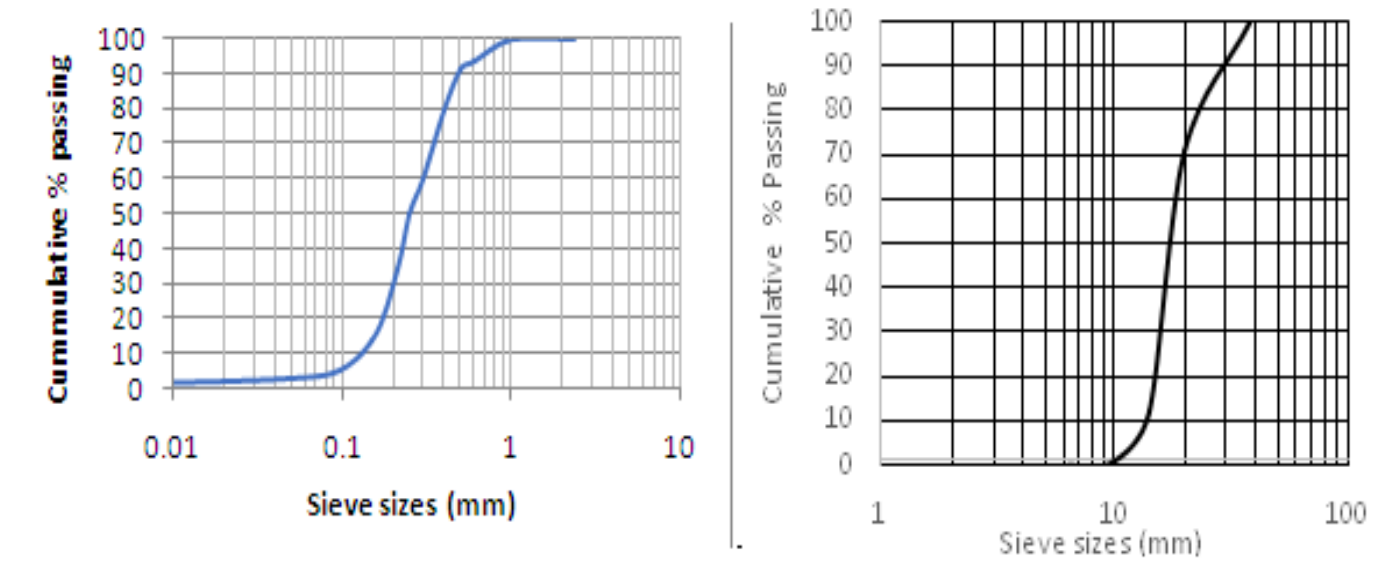

Fig. 1 Particle size distribution of RHA and PKS

Water absorption and moisture content of aggregates

The water absorption capacity was carried out according to ASTM C127 - 15 (2015) in order to determine the capacity of aggregates to absorb water. It was discovered that the rate of absorption of $19 \%$ at thirty minutes of was slightly above that of 24 hours recorded as $14 \%$ for palm kernel shell aggregates. The value of moisture content of palm kernel shell was calculated as $12 \%$ against $1.4 \%$ for sand. The value of water absorption of PKS depends on the volume, distribution and structure of the pores.

\section{Workability of the fresh concrete}

Due to the high absorption of palm kernel shells and rice husk ash, this factor influenced the workability of the concrete. Although the aggregates were in the state of saturation and as such, workability was not greatly affected. From the thirteen mix proportions at constant water and cement content, aggregate was a strong determinant of the compressive strength and slump values. Mix A1 in the Figure 2 had the highest slump value compared to other mix proportions that had varying lightweight aggregates. For the mixes A2, A3, A4, A5 and A6 that has no PKS but with increasing RHA, the slump value was decreasing and the same trend was observed for mixes B2, B3, B4, B5 and B6 with no RHA but increasing PKS. As the sand and granite replacement increase, the slump decreases. Also, increase in the percentage of RHA and PKS requires more water to achieve same level of consistency with the control. This can be attributed to the pores sizes as well as the cementitious property in the RHA that might require extra water for hydration, however, extra water was avoided as this will reduce the strength and the workability level is measured for each mix design. The higher the slump value the better the workability Givi, Rashid, Aziz, and Salleh (2010).

Mix no B2 in the Figure 2 show a symbolic peak which could be interpreted that the optimum workability is achieved at $10 \%$ palm kernel shell and $0 \%$ rice husk ash in the mix proportion. However, the flow of the concrete depends on the intended application. As suggested by the code, the minimum slump value is $25 \mathrm{~mm}$ for any construction: mass concrete, pavements and slabs, reinforced beams, walls, reinforced 
foundations and plain footings with the maximum slump value of $100 \mathrm{~mm}$ according to ACI committee report ACI 211.1-91 (1991)

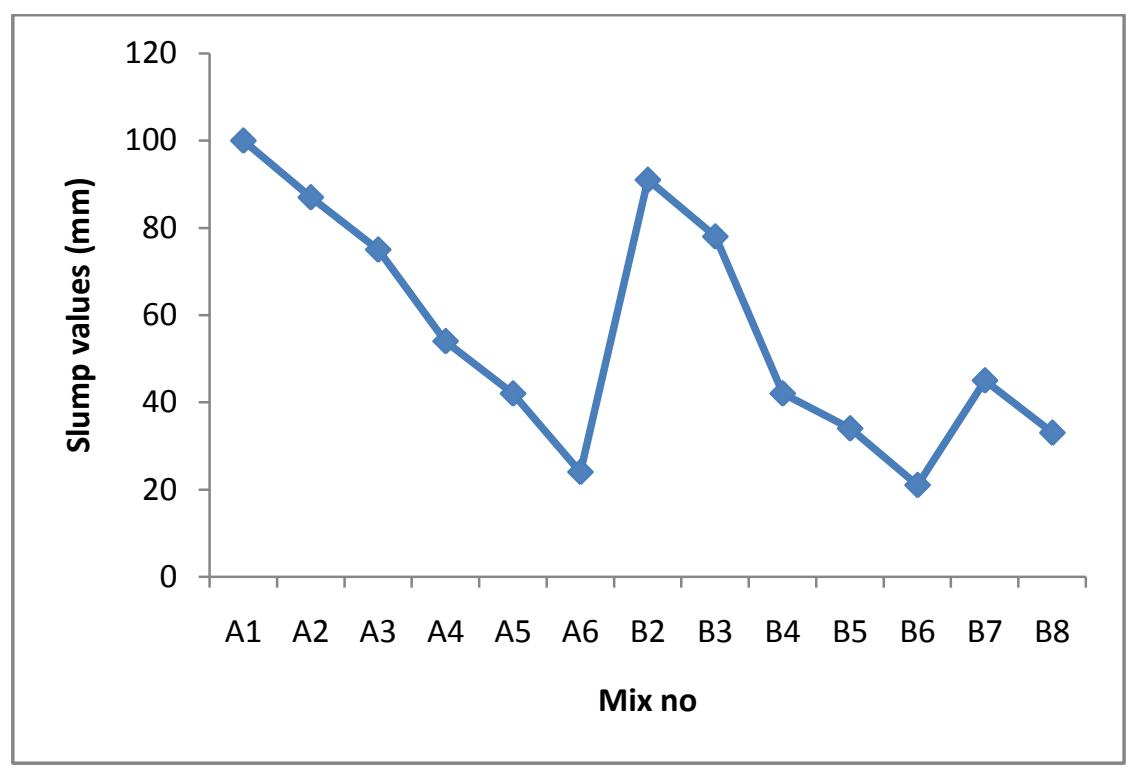

Fig. 2: Workability values of various mixes

\section{Compressive strength of concrete cubes}

Aggregate strength played an important role in the determination of the compressive strength of the lightweight aggregate concrete, having factored water absorption value and cement content in the mix proportion. Compressive strength of the control mix proportion A1 in the Figure 3 slightly achieved higher strength compared to the other mixes that contained RHA except Mix proportion A2. There were three conspicuous peaks at mix numbers A2, B2 and B7 respectively. The higher compressive strength of A2 and B2 could be due lower replacement of sand and granite at $10 \%$. With $10 \%$ of sand replaced by RHA and $0 \%$ replacement for granite, there was $6.61 \%$ increase in the compressive value as compared to the control mix A1, Sales and Lima (2010) accounted for related development. Again, B2 was found to be slightly higher in compressive strength than (A3 - A6) mix proportions, this has also been attributed to different percentages of aggregates in the mix proportions. For the different levels of replacement of sand and granite $(10-100 \%)$ as shown in Figure 3, values of compressive strength ranges between 14.31 and 26.14 MPa. The value of $14.31 \mathrm{MPa}$ (Mix no B6) is lower than the control by almost $71.55 \%$, although there was $100 \%$ replacement for granite with palm kernel shells which is a huge savings in the materials. Mix proportion B7 was found higher in strength when compared to mix proportions (B3 - B6). This could be as a result of 50\% replacement of fine aggregate with pozzolanic rice husk ash as sand and 50\% granite replacement with palm kernel shell which tend to increase compressive strength, similar trend was observed in Sales and Lima (2010) when sand was replaced with bagasse ash up to the $30 \%$. Besides, there is seemingly even distribution of aggregates as sand and granite are equally replaced unlike mix proportions (B3 - B6) that contained no sand replacement except PKS variation. These values are suitable for some classes of work as specified by BS (1997) with a minimum value of 7 and $15 \mathrm{MPa}$ for plain concrete, and reinforced concrete with light weight aggregate. 


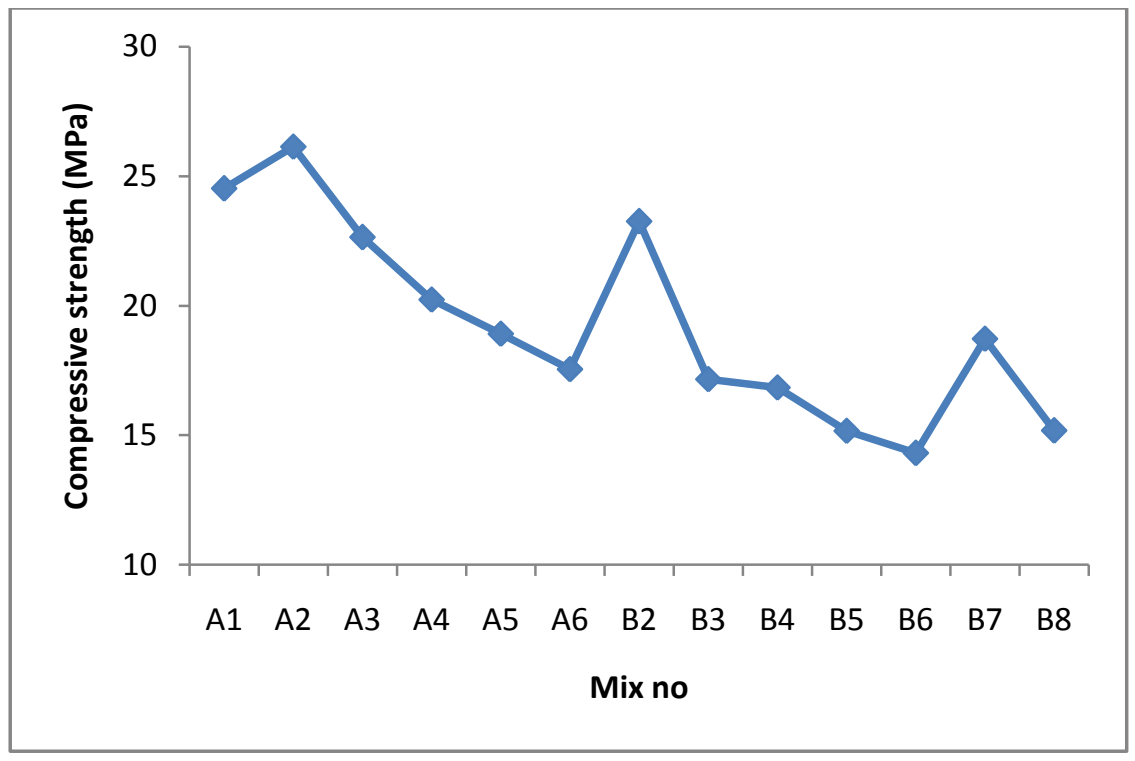

Fig. 3: Compressive strength of samples (MPa)

Density of fresh concrete

Based on the oven-dry density, all the thirteen mix proportions met the stipulated range of 1200 to 2000 $\mathrm{kg} / \mathrm{m}^{3}$ requirement of classification for structural lightweight aggregate concrete, Newman and Choo (2003). The higher values of density could be attributed to the saturation state of the aggregates which in turn increased the density of the concrete. At constant cement content, the factor that influenced density is the relative density of the aggregates. The specific gravities of palm kernel shells and rice husk ash as calculated were 1.54 and 2.57 which are lower than the specific gravities of 2.45 and 2.8 for sand and granite respectively. With this, values of the density of light-weight concrete were reduced compared to the weight of the normal concrete. The hardened density of the samples is shown in Figure 4 and the higher the level of replacement the lower the density.

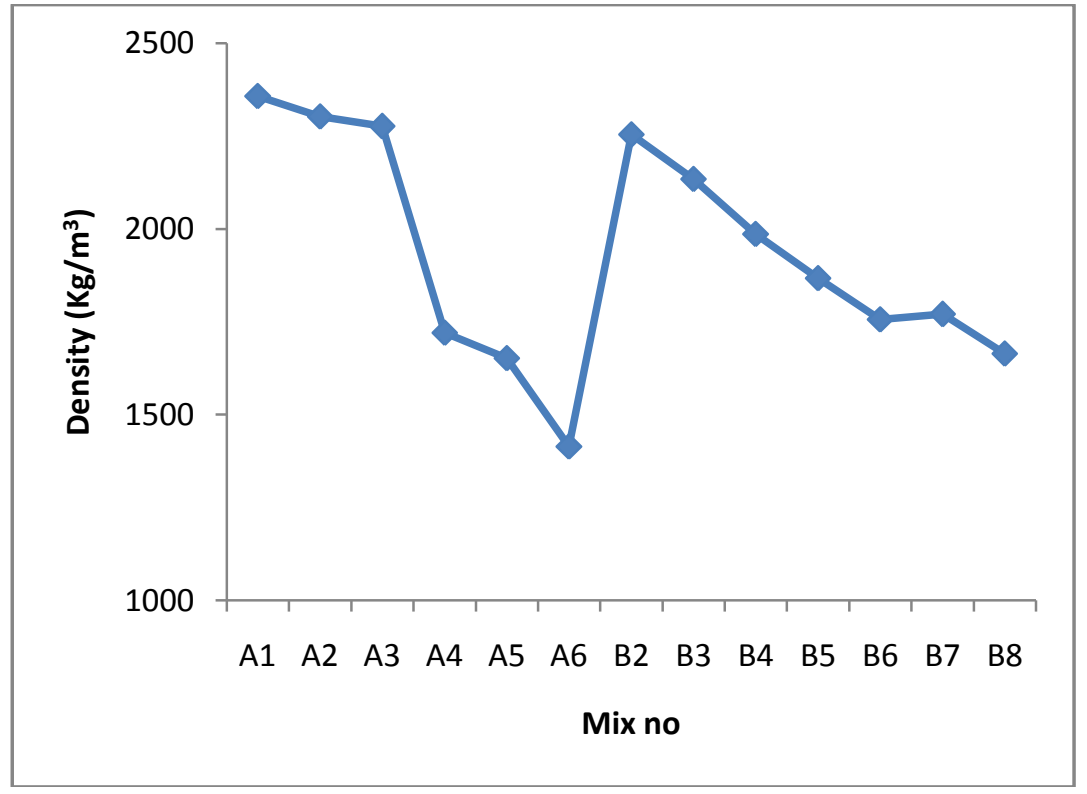

Fig. 4: Oven-dried density

Splitting Tensile and Flexural strength

The purpose of splitting and flexural strength tests is to determine shear resistance provided by the concrete and the highest stress in the concrete before yielding take place respectively. Mix A2 yielded the 
highest value for splitting tensile after the control mix, A1, Figure 5. The trend in the strength was in line with the compressive strength of the Figure 3 . The values of the splitting strength were in the range of 14 to $16 \%$ of the compressive strength which was higher than the values stated in Alengaram et al. (2008). This improved result could be said to be due to relatively good bonding between the cementitous material produced from the hydration of cement with pozzolanic RHA and PKS most especially along their interfacial transition regions.

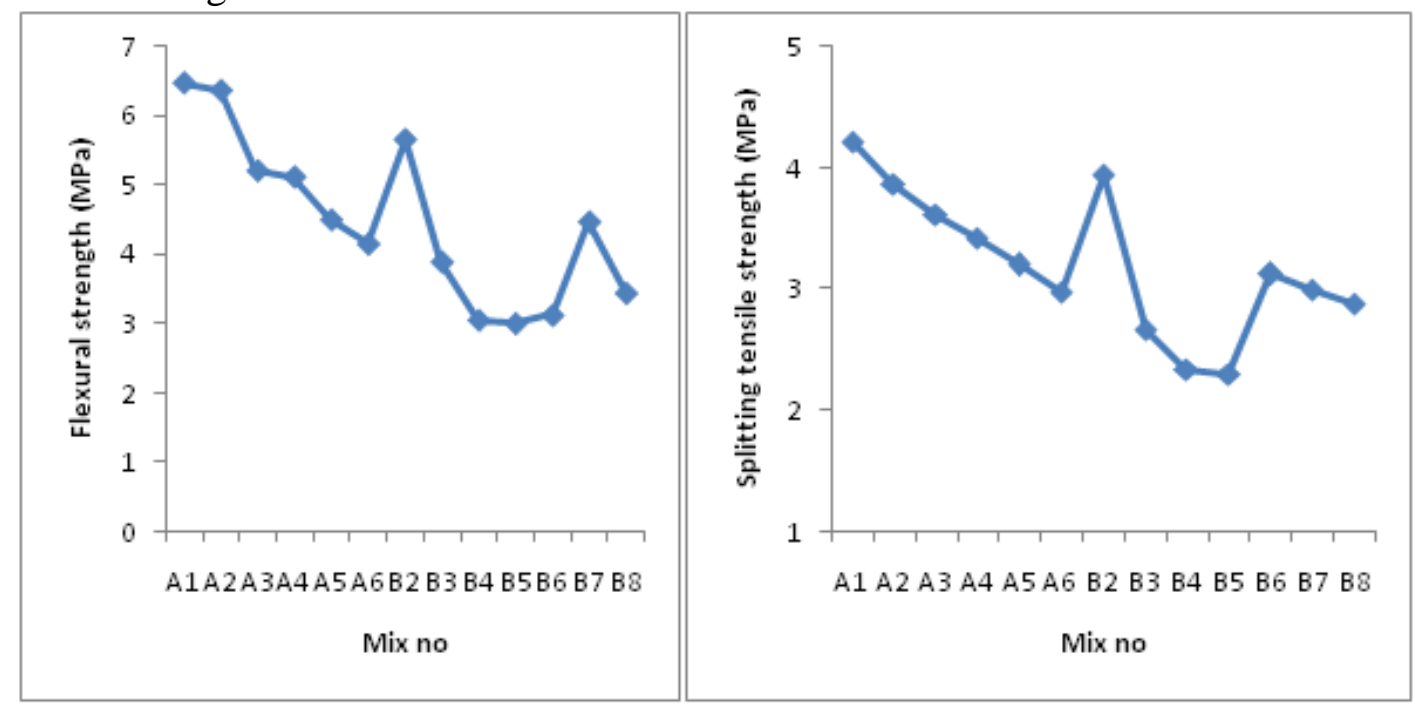

Fig. 5: Results of Flexural and Splitting Tensile Strengths

\section{Conclusion}

This study had demonstrated successful inclusion of high volume of waste products in the production of light-weight aggregate concrete with the following submissions:

1. Adequate compressive strength for light-weight concrete with total replacement of sand and granite with agro-industrial waste products are hereby made possible.

2. From this study and with total replacement of sand and granite, compressive strength value of 15.18 MPa was achieved which is suitable for reinforced concrete with light weight aggregate.

3. The value of workability reduces as RHA replacement increases, however, the improved values of splitting and flexural was a good indicator for reinforced concrete containing palm kernel shells and rice husk ashes as coarse and fine aggregates.

4. The optimum compressive strength at 10\% RHA as sand and 0\% PKS yielded the value of 26.14 MPa while 10\% PKS and 0\% RHA produced compressive strength of $23.25 \mathrm{MPa}$ respectively. Furthermore, with 50\% of sand and granite replaced with 50\% RHA and 50\% PKS, the value of compressive strength was $18.72 \mathrm{MPa}$. These values as well as the other values of compressive strength from this study could be applied for diverse civil engineering applications such as plain and light-weight aggregate concrete.

It is believed that if this research is implemented, it will contribute immensely to the ongoing housing projects in the Country and re-use of agricultural waste products which will in turn reduce environmental hazards from these wastes.

\section{References}

Abalaka, A. E. (2013). Strength Development and Durability Properties of Concrete Containing PreSoaked Rice Husk Ash. Construction Science, 14, 4-12.

Abalaka, E. (2013). Influence of water-binder ratio on normal strength concrete with rice husk ash. International Journal of Sciences, 2(2013-02), 28-36.

ACI 211.1-91. (1991). Standard Practice for Selecting Proportions for Normal, Heavyweight, and Mass Concrete ACI Manual of Concrete Practice, Part, 1, 211. 
Afolayan, J., Amartey, Y., \& Oriola, F. (2015). Effects of Combining Rice Husk Ash And Cement Kiln Dust On The Compressive Strength Of Concrete. International Journal of Advances in Engineering \& Technology, 8(5), 739.

Agbenyeku, E., \& Aneke, I. (2014). Blended Rice Husk Ash Concrete; A Marginal Green Construction Material from Extended Hydration International Journal of Scientific and Engineering Research.

Akogu, E. O., \& Obumneme, G. O. (2013). Strength Development and Durability Prperties of Concrete containing Pre-soaked Rice Husk Ash.

Alabi, A., Olutaiwo, A., \& Adeboje, A. (2015). Evaluation of Rice Husk Ash Stabilized Lateritic Soil as Sub-base in Road Construction. British Journal of Applied Science \& Technology, 9(4), 374-382.

Alengaram, U. J., Jumaat, M. Z., \& Mahmud, H. (2008). Ductility behaviour of reinforced palm kernel shell concrete beams. European Journal of Scientific Research, 23(3), 406-420.

ASTM C127 - 15. (2015). Standard Test Method for Relative Density (Specific Gravity) and Absorption of Coarse Aggregate. ASTM International, 100 Barr Harbor Drive, PO Box C700, West Conshohocken, PA 19428-2959, United States.

ASTM C330. (2006). Standard specification for lightweight aggregates for structural concrete Annual Book of ASTM Standard, ASTM. West Conshohocken, PA: American Society for Testing and Materials.

Ayininuola, G., \& Olaosebikan, O. (2013). Influence of Rice husk ash on soil permeability. $J$ Transnational Journal of Science Technology, 3(10), 29-33.

BS 812. (1975). Methods for Testing Aggregates. London, UK: BSI

BS. (1997). Structural use of concrete. Code of practice for design and construction. London: British Standards Institution Part I.

BS EN 197. (2011). Cement: Composition, specifications and conformity criteria for common cements. London, UK: BSI.

BS EN 1008. (2002). Mixing water for concrete. specification for sampling, testing and assessing the suitability of water, including water recovered from processes in concrete industry, as mixing water for concrete. London, U.K: BSI.

Daneshmand, S., \& Saadatian, O. (2011). Influence of Oil Palm Shell on Workability and Compressive Strength of High Strength Concrete. Annals of the Faculty of Engineering Hunedoara, 9(2), 51.

Ettu, L., Ajoku, C., Nwachukwu, K., Awodiji, C., \& Eziefula, U. (2013). Strength variation of OPC-rice husk ash composites with percentage rice husk ash. International Journal of Applied Science and Engineering Research, 2(4), 420-424.

Givi, A. N., Rashid, S. A., Aziz, F. N. A., \& Salleh, M. A. M. (2010). Assessment of the effects of rice husk ash particle size on strength, water permeability and workability of binary blended concrete. Construction and Building Materials, 24(11), 2145-2150. doi: http://dx.doi.org/10.1016/j.conbuildmat.2010.04.045

Kupaei, R. H., Alengaram, U. J., Jumaat, M. Z. B., \& Nikraz, H. (2013). Mix design for fly ash based oil palm shell geopolymer lightweight concrete. Construction and Building Materials, 43, 490-496. doi: http://dx.doi.org/10.1016/j.conbuildmat.2013.02.071

National Population Commission. (2018). Data for national planning and development http://population.gov.ng/.

Ndoke, P. N. (2006). Performance of palm kernel shells as a partial replacement for coarse aggregate in asphalt concrete. Leonardo Electronic Journal of Practices and Technologies, 5(9), 145-152.

Newman, J., \& Choo, B. S. (2003). Advanced Concrete Technology Processes. Great Britain: Elsevier.

Obilade, I. (2014). Experimental study on rice husk as fine aggregates in concrete. Int J Eng Sci, 3(8), 914.

Ogork, E.-N. N., \& Uche, O. A. (2014). Performance of groundnut husk ash (GHA)-rice husk ash (RHA) modified concrete in acidic environment. International Journal of Engineering Research and Applications, 4(11), 71-77. 
Okafor, F. O. (1988). Palm kernel shell as a lightweight aggregate for concrete. Cement and Concrete Research, 18(6), 901-910.

Okafor, F. O., \& Okonkwo, U. N. (2009). Effects of rice husk ash on some geotechnical properties of lateritic soil. Nigerian Journal of Technology, 28(1), 46-52.

Okpala, D. (1990). Palm kernel shell as a lightweight aggregate in concrete. Building and environment, 25(4), 291-296.

Olanipekun, E., Olusola, K., \& Ata, O. (2006). A comparative study of concrete properties using coconut shell and palm kernel shell as coarse aggregates. Building and environment, 41(3), 297-301.

Onojah, A., Agbendeh, N., \& Mbakaan, C. (2013). Rice husk ash refractory: the temperature dependent crystalline phase aspects. Ijrras, 15(2), 246-248.

Opeyemi, D., \& Makinde, O. (2012). The suitability of partial replacement of cement with rice husk ash and bone powder in concrete structures. International journal of emerging technology and advanced engineering, 2(9), 261-265.

Oyejobi, D., Abdulkadir, T., \& Ajibola, V. (2014). Investigation of rice husk ash cementitious constituent in concrete. International Journal of Agricultural Technology, 10(3), 533-542.

Oyejobi, D., Abdulkadir, T., Yusuf, I., \& Badiru, M. J. (2012). Effect of palm kernel shells sizes and mix ratios on light-weight concrete. Journal of Research Information in Civil Engineering.

Oyekan, G., \& Kamiyo, O. (2011). A study on the engineering properties of sandcrete blocks produced with rice husk ash blended cement. Journal of Engineering and Technology Research, 3(3), 88-98.

PIND. (2011). Palm Oil Value Chain Analysis in the Niger Delta. 1st Floor St. James Building, 167 Ademola Adetokunbo Crescent, Wuse II, Abuja, Nigeria.

Sales, A., \& Lima, S. A. (2010). Use of Brazilian sugarcane bagasse ash in concrete as sand replacement. Waste management, 30, 1114-1122.

TEO, D. C. L., Mannan, M. A., \& Kurian, V. J. (2006). Structural concrete using oil palm shell (OPS) as lightweight aggregate. Turkish Journal of Engineering and Environmental Sciences, 30(4), 251-257.

Tsado, T., Yewa, M., Yaman, S., \& Yewa, F. (2014). Comparative analysis of properties of some artificial pozzolana in concrete production. International Journal of Engineering and Technology, $4(5), 251-255$.

Wbcsd. (2018). Cement-Sustainability-Initiative https://www.wbcsd.org/Sector-Projects/CementSustainability-Initiative.

Yusuf, I. T., \& Jimoh, Y. A. (2011). Palm kernel shell waste recycled concrete road as cheap and environmental friendly freeway on very poor subgrades. Paper presented at the Proceedings of the National Engineering Conference organized by the Nigerian Society of Engineers. Theme: Effective Transportation System in Nigeria: The Way Forward. 